\title{
Treatment of allergic reactions to peanut in recent versus initial reaction
}

Moshe Ben-Shoshan ${ }^{*}$, Luu Nha Nguyen², Reza Alizadehfar ${ }^{1}$, Lianne Soller², Joe Fragapane², Lawrence Joseph ${ }^{2,3}$, Yvan St Pierre ${ }^{2}$, Laurie Harada ${ }^{4}$, Carole Fortin ${ }^{5}$, Mary Allen $^{6}$, Ann Clarke ${ }^{2,7}$

From AllerGen NCE Inc.'s Fifth Annual Research Conference: Innovation from Cell to Society

Québec City, QC, Canada. 7-9 February 2010

\section{Background}

Although studies suggest underuse of epinephrine in food related allergic reactions, it is not clear whether treatment may differ over time in those who have already had an allergic reaction. We sought to characterize treatment of the most recent allergic reaction to peanut versus the initial allergic reaction.

\section{Materials and methods}

Individuals with an allergist-confirmed peanut allergy were recruited from the Montreal Children's Hospital and Canadian food allergy advocacy organizations. Data were collected on initial allergic reactions to peanut and most recent reaction to peanut during the year prior to study entry.

\section{Table 1}

\begin{tabular}{|c|c|c|c|}
\hline & $\begin{array}{l}\text { Epinephrine }+/ \text { - other } \\
\text { medications }\end{array}$ & $\begin{array}{l}\text { Other medications (excluding epinephrine) eg: } \\
\text { antihistamines }\end{array}$ & None \\
\hline Initial reactions, $\%(95 \% \mathrm{Cl})$ & $8.9 \%(5.2,14)$ & $35.6 \%(28.6,43)$ & $55.6 \%(48,62.9)$ \\
\hline Mild & $0.0 \%(0,6.4)$ & $28.6 \%(17.3,42.2)$ & $\begin{array}{l}71.4 \%(57.8 \\
82.7)\end{array}$ \\
\hline Moderate & $7.7 \%(3.1,15.2)$ & $37.4 \%(27.4,48.1)$ & $\begin{array}{l}54.9 \%(44.2, \\
65.4)\end{array}$ \\
\hline Severe & $27.3 \%(13.3,45.5)$ & $42.4 \%(25.5,60.8)$ & $\begin{array}{l}30.3 \%(15.6 \\
48.7)\end{array}$ \\
\hline Treated only outside HCF & $0.0 \%(0,9.3)$ & $100.0 \%(90.7,100)$ & \\
\hline Treated only in HCF & $44.8 \%(26.4,64.3)$ & $55.2 \%(35.7,73.6)$ & \\
\hline Treated outside and in HCF & $40 \%(5.3,85.3)$ & $60 \%(14.7,94.7)$ & \\
\hline Location unknown & $12.5 \%(0.3,52.7)$ & $87.5 \%(47.3,99.7)$ & \\
\hline $\begin{array}{l}\text { Most recent reactions \% }(95 \% \\
\text { Cl) }\end{array}$ & $17.2 \%(12,23.5)$ & $62.2 \%(54.7,69.3)$ & $\begin{array}{l}20.6 \%(14.9, \\
27.2)\end{array}$ \\
\hline Mild & $5.7 \%(1.2,15.7)$ & $64.2 \%(49.8,76.9)$ & $\begin{array}{l}30.2 \%(18.3 \\
44.3)\end{array}$ \\
\hline Moderate & $16.5 \%(9.7,25.4)$ & $63.9 \%(53.5,73.4)$ & $\begin{array}{l}19.6 \%(12.2 \\
28.9)\end{array}$ \\
\hline Severe & $40 \%(22.7,59.4)$ & $53.3 \%(34.3,71.7)$ & $6.7 \%(0.8,22.1)$ \\
\hline Treated only outside HCF & $8.8 \%(3.9,16.6)$ & $91.2 \%(83.4,96.1)$ & \\
\hline Treated only in HCF & $20 \%(2.5,55.6)$ & $80 \%(44.4,97.5)$ & \\
\hline Treated outside and in HCF & $64 \%(42.5,82)$ & $36 \%(18,57.5)$ & \\
\hline Location unknown & $29.4 \%(10.3,56)$ & $70.6 \%(44,89.7)$ & \\
\hline
\end{tabular}

$\mathrm{Cl}$, Confidence interval; $\mathrm{HCF}$, Health Care facility 


\section{Results}

See Table 1

Among 180 individuals reporting both an initial allergic reaction and a recent allergic reaction to peanut, epinephrine was administered in $8.9 \%$ (95\% CI, 5.2-14.0\%) and $17.2 \%$ (95\% CI, 12.0-23.5\%) respectively. Treatments excluding epinephrine were given in $35.6 \%$ (95\% CI, 28.6-43.0\%) of initial reactions and in $62.2 \%$ (95\% CI, 54.7-69.3\%) of most recent reactions. Among those treated only outside health care facilities (HCFs) no participant received epinephrine in initial reactions versus almost 9\% (95\% CI, 3.9-16.6\%) in most recent reactions. However, in initial reactions, $44.8 \%$ (95\% CI, 26.4-64.3\%) of those treated, only in HCFs received epinephrine compared to $20 \%$ (95\% CI, $2.5-55.6 \%$ ) in recent reactions. Almost 1/3(95\% CI, 15.6-48.7\%) of participants with a severe reaction did not receive any treatment for the initial reaction compared to $6.7 \%$ (95\% CI, 0.8 $22.1 \%)$ of those with a recent reaction.

\section{Conclusions}

Although there is higher use of epinephrine in recent reactions compared to initial reactions, it is still administered in only $40 \%$ of severe allergic reactions. Further, our results suggest decreased epinephrine use over time in those treated initially in HCFs concurrent with increased use of other treatments such as anti-histamines. Given that prompt administration of epinephrine is the principal therapy for food-related anaphylaxis, it is crucial to develop and distribute guidelines and education programs that would contribute to increase epinephrine use inside and outside HCFs.

\footnotetext{
Author details

${ }^{1}$ Division of Pediatric Allergy and Clinical Immunology, Department of Pediatrics, McGill University Health Center, Montreal, Canada. ${ }^{2}$ Division of Clinical Epidemiology, Department of Medicine, McGill University Health Center. ${ }^{3}$ Departments of Epidemiology and Biostatistics, McGill University, Canada. ${ }^{4}$ Anaphylaxis Canada (AC), Canada. ${ }^{5}$ Association Québécoise des Allergies Alimentaires (AQAA), Canada. ${ }^{6}$ Allergy/Asthma Information Association (AAIA), Canada. ${ }^{7}$ Division of Allergy and Clinical Immunology, Department of Medicine, McGill University Health Center, Canada.
}

Published: 26 November 2010

doi:10.1186/1710-1492-6-S3-P29

Cite this article as: Ben-Shoshan et al:: Treatment of allergic reactions to peanut in recent versus initial reaction. Allergy, Asthma \& Clinical Immunology 2010 6(Suppl 3):P29.

Submit your next manuscript to BioMed Central and take full advantage of:

- Convenient online submission

- Thorough peer review

- No space constraints or color figure charges

- Immediate publication on acceptance

- Inclusion in PubMed, CAS, Scopus and Google Scholar

- Research which is freely available for redistribution

Submit your manuscript at www.biomedcentral.com/submit 